
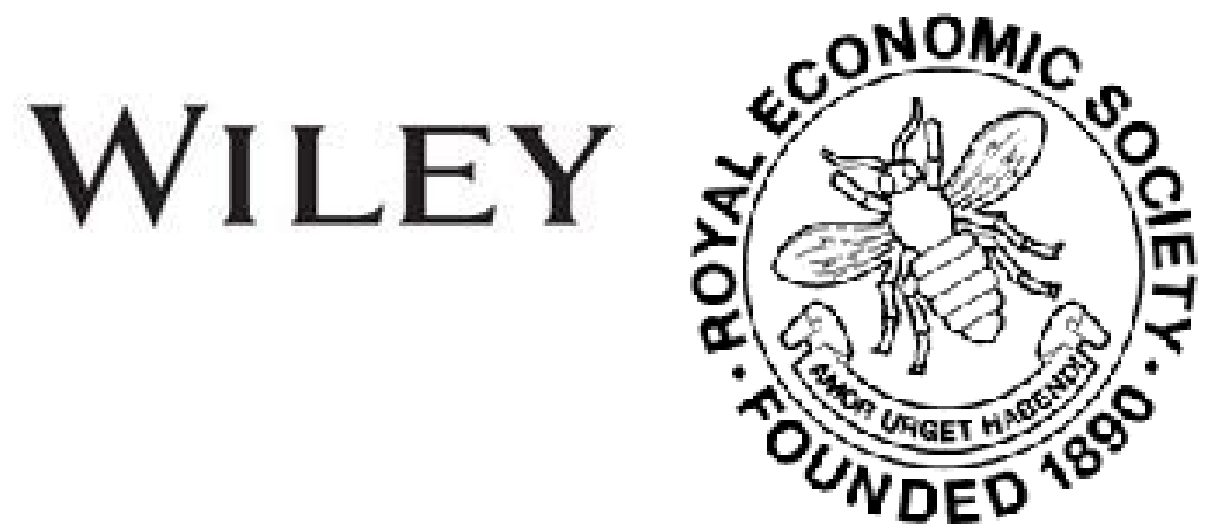

The Census of 1911. A Forecast of its Results Author(s): A. R. Burnett-Hurst and Israel Horwitz

Source: The Economic Journal, Vol. 21, No. 81 (Mar., 1911), pp. 148-151

Published by: Wiley on behalf of the Royal Economic Society

Stable URL: http://www.jstor.org/stable/2222095

Accessed: 27-06-2016 06:14 UTC

Your use of the JSTOR archive indicates your acceptance of the Terms \& Conditions of Use, available at

http://about.jstor.org/terms

JSTOR is a not-for-profit service that helps scholars, researchers, and students discover, use, and build upon a wide range of content in a trusted digital archive. We use information technology and tools to increase productivity and facilitate new forms of scholarship. For more information about JSTOR, please contact support@jstor.org.

Wiley, Royal Economic Society are collaborating with JSTOR to digitize, preserve and extend access to The Economic Journal 
tigation, I am glad to have the present opportunity of again acknowledging obligation to Mr. Bickerdike's article on Incipient Taxation. $^{1}$ In the course of the investigation it appears that the comparative advantage does not rest so fundamentally, as sometimes conceived, on the principle of joint cost or increasing returns. For example, suppose the State to own and work two distinct railways or canals, similar as touching their cost, but differing in respect of the demand for transportation. Probably in such a case the State might prescribe a different scale of rates on two lines, with benefit to the public as a whole. The benefit need not depend at all on joint cost or increasing returns. We might suppose, for the sake of illustration, natural waterways for which the costs of construction and all general expenses, involving the possibility of increasing returns, are negligible. The benefit depends on a quite different principle, the avoidance of that perte sêche, in M. Colson's phrase, that loss of Consumers' Surplus which is incident to a unitary price. That the benefit may be measured by comparison with the state of the customers as it "would have been, other things being equal, under a régime of competition"- whatever that may mean in the case supposed -is at best a secondary proposition. ${ }^{2}$ It is an obiter dictum not worth disputing about, but for its accidental connection with more important topics to which attention has been called by Mr. Bickerdike.

F. Y. EDGEWORTH

\section{The Census of 1911.}

\section{A Forecast of its Results.}

IT is an unbroken tradition of the Economic JodRNaL to contain a forecast of the population revealed by the Census. Dr. Longstaff ${ }^{3}$ came within $0 \cdot 2$ per cent. in his estimate of the population of the United Kingdom in 1891, and Prof. Cannan ${ }^{4}$ within 0.6 per cent. in 1901.

We have constructed the following table for the intercensal period 1901-11.

1 Economio Journal, 1907, p. 101 ; cp. Economic Jodrnal, 1908, p. 399 et seq. 1910, loc. cit.

2 So described, loc. cit., p. 448, par. 2.

3 Economic JournaL, Vol. I., p. 382.

4 Ibid., Vol. XI., p. 230. 


\begin{tabular}{|c|c|c|c|c|c|}
\hline & $\begin{array}{l}\text { United } \\
\text { Kingdom. }\end{array}$ & Ireland. & $\begin{array}{c}\text { Great } \\
\text { Britain. }\end{array}$ & Scotland. & $\begin{array}{c}\text { England and } \\
\text { Wales. }\end{array}$ \\
\hline Population in $1901 \ldots$ & $41,458,721$ & $4,458,775$ & $36,999,946$ & $4,472,103$ & $32,527,843$ \\
\hline $\begin{array}{ll}\text { Natural increase } & \ldots \\
\text { Net emigration } & \ldots\end{array}$ & $\begin{array}{l}+4,847,651 \\
-1,254,000\end{array}$ & $\begin{array}{l}+257,242 \\
-342,000\end{array}$ & $\begin{array}{l}+4,590,409 \\
-\quad 912,000\end{array}$ & $\begin{array}{l}+541,858 \\
-250,000\end{array}$ & $\begin{array}{l}+4,048,551 \\
-\quad 662,000\end{array}$ \\
\hline Estimate for $1911 \ldots$ & $45,052,000$ & $4,374,000$ & $40,678,000$ & $4,764,000$ & $35,914,000$ \\
\hline
\end{tabular}

\section{Natural Increase.}

For the period from April 1st, 1901, to December 31st, 1910, this item is obtained from the Annual Reports and the Quarterly Returns of the Registrars-General. An estimate based upon the trend of the excesses for the first three months of the years 1900-10 has been made for the first quarter of this year.

\section{Net Emigration. (1) United Kingdom.}

In the tables relating to Emigration and Immigration from and into the United Kingdom (H. of C. 137, 1910) we find in the Summary Tables (A and B) a detailed analysis of the "Passenger Movement between the United Kingdom and nonEuropean countries" (Table A) and of the "Passenger Movement between the United Kingdom and European countries" (Table B)-both since 1900. In the case of Table A, there is a large balance outward; whilst in the second table there is a balance inward, ${ }^{1}$ the difference giving the total balance outward. As regards the first quarter of 1901, an estimate has been made by taking the proportions of immigration during the first quarters of $1905,1906,1907$, and $1909^{2}$ (obtained from the monthly reports published as a result of the Aliens Act) to the total immigration during the whole of those respective years, and then taking the average of these four proportions, which were all very close to each other. The resulting proportion enables us to obtain the net emigration for the first three months of 1901, whence, by subtraction, the net emigration for the last three quarters of 1901 is obtained. Again, the net emigration for 1910 is estimated from the returns of 1901-9, while the same method is adopted as in the case of the first three months of 1901 to forecast the return for the first quarter of this year.

1 Except for 1908, when there was a balance outward.

21908 omitted, as being an exceptional year. 
We have added to the Board of Trade immigrants 120,000 for soldiers returning after the South African War, but have also added 20,000 to the Board of Trade emigrants for the increase in the Navy and Merchant Service abroad.

(2) Ireland.

As regards the population of Ireland, the Irish RegistrarGeneral keeps a record of the number of emigrants "leaving Ireland with the intention of permanently settling elsewhere." Cd. 5,088 of 1910 gives returns for the last nine months of 1901 and 1902-9 inclusive. We have based our estimate of the number of emigrants who left Ireland in 1910 and in the first quarter of 1911 upon the general trend of the figures and also upon the quarterly variations.

In the three previous intercensal periods the Irish RegistrarGeneral's figures for permanent emigration have differed from the total net emigration from Ireland as follows:-In 1871-81 they were 53,000 less than the total net emigration; in 1881-91 they were 36,000 more, and in 1891-1901 33,000 less. With these facts before us, we have thought best to assume that the immigrants and the unrecorded emigrants of 1901-11 will balance each other.

(3) Great Britain.

The 912,000 of net emigration is obtained by subtracting the Irish net emigration from that of the United Kingdom.

(4) Scotland.

The difficulty now is to divide the net emigration from Great Britain between England (with Wales) and Scotland. In 18911901 the net emigration was so small as to afford us no guidance. In 1881-91, when the net emigration from Great Britain amounted to 819,000 , the distribution was as follows :England 601,000, Scotland 218,000. The gross emigrants of Scottish nationality to non-European countries during that period were 275,000 ; in $1901-11$ it appears that they will have been about 460,000 , whereas the corresponding figure for England will have only risen from $1,548,000$ to about $1,860,000,{ }^{1}$ so that it appears justifiable to expect that the Scottish net emigration has been higher in proportion to the English in 1901-11 than in 1881-91. The only other fact upon which we can rely is that the immigrants from non-European countries of persons of Scottish nationality in 1901-11 appear to be about 175,000, but there are no corresponding figures for previous decades. With these facts before us, we have concluded that the net emigration

1 H. of C. 137, 1910. Table A for 1901-9 and Cd. 5056-xi. for 1910. 
from Scotland is likely to amount to 250,000 , after allowing 10,000 for soldiers returning after the South African War.

(5) England and Wales.

The 662,000 of net emigration is the remainder of the net emigration from Great Britain.

For comparison we append the populations for 1911 calculated as estimated by the method officially adopted in England, i.e., on the assumption that the increase or decrease of each of the three kingdoms continues at the same rate as in the previous intercensal period :-

\begin{tabular}{lr} 
England and Wales.......................... & $36,481,000$ \\
Scotland ....................................... & $4,968,000$ \\
Ireland .............................. & $4,226,000$ \\
\hline United Kingdom........................ & $45,675,000$
\end{tabular}

It should be noticed, however, that if the population of the United Kingdom were estimated by this method as a whole, it would only amount to $45,553,000$. If the United Kingdom were England, and the three kingdoms parts of England, the official method would involve adjustment of the populations of England, Scotland and Ireland to make them jointly amount to the $45,553,000$.

\section{A. R. Burnett-Hurst IsRAEL Horwitz}

The Economic Legislation of the Year 1910.

OwING no doubt to the unsettled condition of politics during the year 1910, the Government did not promote any Bills of firstrate importance, and its output was very small, the number of public general Acts being much below the average of the last few years.

The Appropriation Act (C. 14) authorises the Treasury to raise the necessary funds for the supplies granted for the service of the year ending March 31st, 1911. The appropriations to the various services amount to 136 millions, being 10 millions in excess of the amount appropriated last year. The Naval vote of 42 millions shows an increase of 5 millions on the previous year; the amount allocated to the Army remained at 31 millions. The grant for Education has risen to $18 \frac{3}{4}$ millions, being an increase of nearly three-quarters of a million.

The Finance (1910) Act (C. 8) gives effect to the Budget (1909-10) which was not passed until a month after the expiration 